\title{
ETHNOSEMANTICS IN EVERYDAY SINGLISH
}

\author{
Kun Aniroh
}

\begin{abstract}
Widely used in the world, English has grown to many varieties in which one of them is everyday Singlish. Singlish is a kind of English spoken by Singaporean communities in informal situations. In everyday Singlish lexicons not found in original English are ubiquitously used. The area of concern of etlinosemantics is the one with the appearance of the lexical semantics in a certain language. These lexicons have certain meanings, flavours and nuances that make a language specific and unique. This is due to the fact that this specific lexicon use has a close connection with a particular culture and race. The study of ethnoserr-antics in everyday Singlish shows that the uniqueness is closely related with Singaporean cultures. There fore, the study of ethnosemanties which is explorable from local varieties will help understand the cultures, the characteristics and the life of Singaporeans as a speech community.
\end{abstract}

\section{Keywords}

Lexical Semantics, Culture, Race, Communication Across Culture

\section{Introduction}

English that was originally spoken in the land of English leas .now become widespread in use as a global language a lingua franca. The countries considered close in terms of cultures and distance to those in the motherland of English have relatively the same varieties of English, These similarities are commonly observable in the grammatical structures; while in terms of vocabulary and pronunciation they may be found a little bit different. However, in the countries where the geographical distance is notable and the cultural aspects are apparently different, Englishes grow along with the local culture in those countries. As what Hymes argues that one language means one culture, the ethnographic world can be divided into linguistic units; each associaing with three important aspects as cul tures, the organization of speech as communicative means, and the resources and organization of communication across culture (Hymes in Sanchez and Blount, 1974; Hymes in Blair,1982).

The growth of specific English in a certain country cannot be avoided as the more intense use of English as a means of communication in the global world. The specificity of English in these localities presents a certain 'flavour' and 'colour' originating from the local culture and this results in a variety of English which may be different from English spoken in England, or North America, or elsewhere. With this, and with the growth of local varieties of English, a native speaker may have to Iearn certain characteristics features of a national or local variety of English. Thus, an Englishman may have to 'deEnglisize' himself and an American needs to 'deArnericanize himself in order to understand these national varie-ties (KaChru, in Sibayan, 1984).

A fear of communication problems was encountered due to the local English when several students of Diploma III in Tourism, Merdeka University, Malang, being an Indonesian accustomed to learning 'a standard English' in the English class in Indonesia, had to go to 
Singapore to attend an on-the-job training course there. The problem gradually emerged, following the May tragedy in 1999 in which there was a violent riot in big cities in Indonesia especially Jakarta, and the situation was worsened with the appearance of the global monetary crisis and that of the terrorism issues. The bilateral communication between Indonesia and Singapore at that time was a little- bit disturbed by a strong and ungrounded statement of the Big Prime Minister Lee Kuan Yew that Indonesia was a safe place for terrorists to live and grow. Because of this situation, then, the Human Resources Manager of some hotels in Singapore preferred to interview students not in person but through a telephone talk. Phone interviews went on. Btit, as , result of this phone interview policy, many students interested in joining the on-thejob training in Singa-pore hotels complained that they did not understand Singlish lexi-cor,s spoken by the hotels' Human Resources Managers. Further-more, the interviewer spoke very quickly not in a normal form of conversation (This seems to be understandable because interconti-nental phone talk can be very expensive to carry out).

As used in everyday Singapore's life in informal situations, Singlish or Singaporean English indeed has developed on its own 'colour' and 'flavour', detracting itself from its main course either American or British Englishes. And this has forced other speakers of English to learn more about it In order to come tip with a mutual understanding in daily verbal communications. The teaching of local variety of English to learners in the classroom is still debatable, however. The proponents of the standard variety are afraid of natural incidents of the so-called 'pidginazation' that may fossilize in the learners' language performance. However, when the learners need it as the case of the students of Diploma Ill in Tourism, Merdeka University Malang having interviews with Singaporeans, it is proper to introduce the local variety to the learners for the sake of both integrative and instrumental functions of language.

This paper tries to discuss Singaporean English focussing on the daily speaking communication made by the Singaporean community in relation to ethnosemantics. For the purpose, the discussion includes dynamic interactions of' language use, race, culture, the role of meaning in speaking, and lexical semantics What is Ethnosemantics?

Ethnosemantics has the relation with ethnoscience. It deals with lexical features of semantics on which lexical domains are based and organized. The general goal of ethnosemantics as originally formulated was the discovery of folk taxonomies, utilizing rigorous methods and techniques in the research design and procedure (Sanchez and Blount, 1975). It is also concerned with ethnography in which one of the shdies is entitled 'Ethnography of Speaking' proposed by Hymes ( Hymes, 1974: 189 in Blount, 1974).

On lexical domains, native speakers find that lexical errors ore more disruptive than grammatical errors. Grammatical errors generally result in structures that are still understood, whereas lexical errors may interfere with communication. (Gass and Selinker, 1994:270).

Ethnography of speaking which emphasizes on the aspects of speech events consisting of the acronymized elements SPEAKING, being 1) (S) Setting referring to the time and place; 2) (P) the participant i!lcluding various combinations of acts between speakorlistener, adressoraddressee, or sender-receiver; 3) (E)End referring to the conventionally recognized and expected outcomes of an exchange; 4) (A)Act sequence, referring to the actual form and content of what is said to; 5) (Key), referring to the tone manner or spirit in which a particular message is conveyed, lighthearted, precious, se-rious, etc; 6) (I) Instrumentalities, referring to the choice of channel, e.g. oral or written, 7) (N) Norms, being the specific behavior and properties that attach 
to speaking; 8) (G) Genre, referring to the types of utterances such things, poems, proverbs, riddles, sermons, prayers, lectures and editorials (Hymes, 1971).

Hymes'formula on ethnography of speaking is a necessary reminder that talk is a complex activity, and that any particular talk is actually a piece of skilled work. He has suggested kinds of !an-guage in one hand and uses of language on the other hand and ac-cepted that there will be probably not to be one-to-one mapping of these different members in speech community (Hymes in Romain`e 1982).

\section{Language, Race and Culture}

Language has a setting, The people that speak it belong to a race or a number of races, that is, to a particular group which is set off by physical characteristics from other groups, Again, language does not exist apart from the culture, that is from the socially inherited assemblage of practices and beliefs that determines the texture of our lives (Sapir, 1949:207). He furthermore states that culture may be defined as what a society does and thinks; race refers to an intangible aspect called "temperament", and language is a particular of how of thought. Hudson (1982:74) defines society's culture as consisting of whatever it is one has to know or believe in order to operate in a manner acceptable to its members. Similarly Wardaugh (1992:217) defines culture as to know how that a person must possess to get through the task daily living.

Based cn that explanation above, it seems apparent that when people speak the element of' what society does or thinks and their temperaments underlie their speech. A clear example of this can be seen that every language has its own pitch, juncture, and rhythm that expresses culture and temperament.

\section{The Role of Meaning in Speaking}

Talk is a complex activity and it covers many aspects before it reaches comprehension. One of the aspects which helps talk or speaking to be successful is the delivery of meaning. There are three sets of meaning theory as proposed by Cooper (1973), These include the mentalistic theory, the behaviorist theory, and the use theory. The mentalistic theory refers to versions which holds that an expression is meaningful if only if it is associated, in some manner, with a certain mental item-an image, say a thought or an idea.

The behaviorist theory refers to several versions which holds that an expression is meaningful if only if utterances of it produce certain behavioral responses in people and or are produced in response to stimuli. Two expressions will be synonymous correspondingly, if and only if utterances of them produce the same response to the same stimuli. Based on this view, examining meaning is essentially a matter of examining behavior connected with utterances or expressions.

The use theory refers to several versions that hold that an expression is meaningful if and only if people can use it for certain purposes and in certain ways. Two expressions correspondingly will be synonymous if only if they can be used in the same ways, for the same purposes, On this view, examining meaning is essentially a matter of examining the role that expressions have in human activities.

\section{Lexical Semantics in Everyday Singlish}

The focus of ethnosemantics is lexical semantics. Lexical semantics is also concerned with words and nuances. As quoted by Gass and Selinker (1994:277), Tudorov defines that every 
word gives off the scent of a profession, genre, current, party, particular work, particular man, generation, era, day, hour and soon. Every word smells of the context and contexts in which it has lived its intense social life.

In everyday Singlish there are many lexicons that give special colour and flavour that make everyday Singlish has its own unique characteristics. As is known, Singaporean community consists of mixed people such as Chinese, Indians and Malaysians and others. Chinese is the majority of population, the next is Malaysians, and Indians. In their own ethnic contexts, Chinese speak Mandarin and Malay, Malaysians speak Malay and Indians speak Malay, but they all speak English, for English is a second language in Singapore. Hymes (1974:5 in Blount) explains cross communication among each of different ethnic groups associates with themselves with their culture, the organization of speech as communicative means, resources and organization. Communication across cultures then takes place. The three major communities in Singapore share their colour coming from their language, and this can be seen from an example of the conversation below.

Here are some dialogues of Indonesian trainees who speak Singaporean English. They stayed in Singapore for six months. These dialogues were recorded shortly after they came back to Indonesia. Another is a story told by a housemaid who has lived in Singapore for three years (Muhrofie, 2000).

\section{At the Apartment}

Viand : Had, where you stay $a$ ?

Hadi : In Pasir Ris lah. How come you forget'?

Viand : Oh, iya sorry I forget. Had, your landlord nice $a$ ?

Hadi : Not too lah. Sometimes they getting angry if I go home too late coz they had to wait for me until I get back home

Viand : Why? You not bring the key $a$ ?

Hadi : Sometimes I bring, but usually I forget to bring

Viand : No wonder lah, but if I want to play to your apartment, your landlord not angry a?

Hadi : When you want to go there?

Viand : Maybe this Monday I go there, but you are sure a your landlord never angry if I go there?

Hadi : Sure lah

Particle /a/ which is pronounced in high intonation is an In-dication of' an influence of Mandarin, Mandarin is the language that applies high and low intonation. Particle /lah/ is likely the influence of Malay/Malaysia for emphasizing something. Based on Hymes' idea on 'genre, that is 
type of utterances that refers to things, the presence of particles /a/ and /lah/ provides a certain meaning to en-sure something. If the particle is eliminated the nuance of the sen-tence will sound different; there will be a kind of absence of the feeling of intimacy or closeness. This can also be referred to mentalistic theory which refers to an expression is meaningful if only if it is associated, in some manner, with a certain mental item-an image, say a thought or an idea. Therefore the presence of /a/ and /lah/ gives the strong image, associating with emphasizing and promising.

What does that word mean? Londlord means someone who runs a rooming house, inn or innkeeper. In this sentence the meaning refers to the first. The expression I want to play to your apartment, your landlord not angry sounds very much to be like Singaporean or Malaysian or even Indonesian. The expression implies that the owner of the house -a Singaporean- feels disturbed when there are many people or friends of the tenants coming over with their friends. There is a reason for that. That is, the majority of Singaporeans live in a flat that is not big enough to cater for many people. Therefore, when there are some. people -Indonesians like to go in group- come to their flat, their privacy becomes disturbed.

Related to the behavioristic theory, an expression will be meaningful only if utterances produce certain behavioral responses in people and or are produced in response to stimuli. In that dialog quoted above the speaker wants to know whether the landlord will be angry or not by asking angry or not twice: your landlord not angry a; your landlord never angry a? These two utterances show that the speaker wants to make sure if he or she comes over there everything is fine with the landlord. He already knows that living with a landlord sharing a room in a narrow flat is not quite comfortable, but the interlocutor gives the information that his landlord is not angry. Hadi, one of the interlocutors does not want to lose his face if lie comes to his friend apartment and the landlord is angry. This expression shows that certain behavior, that is coming to the ment will cause certain 'unwanted behavior' on the part of the land-lord. Therefore, Hadi has to ask questions twice to make his feeling safe. Now consider the following dialog.

\section{Shopping Arcade}

Ary : I am very happy you accompany me for shopping

Lessy : That's good lah. Ws nice to be with you what. I'm happy

Ary : Hey, look at this gown!

Lcssy : This is very nice you know. You buy lah it'you want

Ary : No lah, I have no money right now. Maybe next time lah.

Lessy : Ok. Let's take a look at other boutiques.

Ary : Wow. It's crowded here.

Lessy : It's Sunday what

Ary : 0.... ya. o I forget. Hey.... that shirt, nice lah. I wanna see it. Come! 
Lessy : This shirt for kids lah. It won't fit you

Ary : It's not for me what. It's for my sister's daughter . She's three years old

Lessy : Have you seen the price? It's expensive 0

Ary : Ha... no need lah. Just forget it. It's too expensive. Let's go!

There are three utterances that sound unique: what in It's nice to be with you what! It's Sunday what; It's not for me what.

The three whats in the three sentences appear at the end of every sentence. The function of what here is to make sure something is as the way it is. The speaker in the first sentence expresses her feeling that she likes Ary, as she has known her and she usually goes with her. The second sentence tells about Sunday in which on Sundays there are always many people, they know it already, but one of them may forget that the day was Sunday. The last sentence It's not for me what, the speaker already knows that the shirt is for the kid, anyway she still says it to make it sure. If those utterances are related to tile use theory which states that an expression is meaningful if people can use for certain purposes in certain ways, the use of what at the end of the sentence by the speaker is meaningful and useful in the sense that the use of what can represent the real situation that are expressed by the utterances. Next, have a look at the following.

\section{At the Food Court}

A : Hey what' takes you so long'?

B : It's so early you go back

A : Ya... I work faster today. Do you want to eat something'?

B : I buy you. I got a lot of tips today

A : Wow okey. What everything looks nice.

What about you, what do you want to eat?

B : I think I wanna try Hokkian mee, please. 0.. wait a minute

Does it contain pork?

A : No, it's halal food

B : Hey I wanna try roasted duck. It smells good

A : Auntie, one roasted duck please! 
Auntie, I sit down over there $a$ thank you

In the dialog quoted above there are some lexicons and ex-pressions that also sound very Singaporean: I buy you; I wanna try Hokkian mee and Auntie. I buy you means B wants to treat A. This sentence is short, expressive and meaningful. The second sentence I wanna try Hokkian mee, is the mixed result of the American English (wanna) and the Chinese (Hokkian mee) influences. The last is the word Auntie expresses when the speaker buys something at a restaurant shows politeness. Instead of saying waiter or waitrees the speaker says Auntie. Cross communication culture takes place in the second and the third sentence, which means that the buyer is still young and the waitress is a middle-aged woman. In the Asian culture, it is considered impolite to call someone who is older only by mentioning name, and Auntie is the proper word for that. Consider what follows:

\section{A Story of Sutiasih}

My name Sutiasih. I am twenty three year old. I'm from Malang. I have working in Singapore two year. In Singapore I cook, clean the house, cooking and take care of ama and child. I can know how to Indonesia and I happy. I

send my money every six month. I send only three million. Half I put in bank and half for my parents. In Singapore I have holiday, from the morning I go with my friends then I can play all day after that I coming back to house.

I happy and how Singapore I know, in Singapore so very nice. If I have holiday I go shopping, I go to Sentosa, I can see niany people, I go to city hall. In city hall I can see many flower and if I'm hungry, I buy fried chicken and the fried chicken one piece is 3 dollar or 5 dollar. If in the house I eat cheetam. In the morning I eat breakfast, afternoon I eat noodle and night I eat porridge or rice and I sleep ten o'clock. I wake up at 5 or 4.30. 1 live in the house in flat on the sixth floor on the flat number 34 .

I live in flat with my employer. Evryday my employer working to office then at six o'clock my employer go, coming back six o'clock. If my employer not in I stand by with my ama.

As seen in the quotation above, the story told by Sutiasih is full of cultural values of Java. As defined by Hudson (1982) culture consists of whatever it is one has to know or believe in order to operate in a manner acceptable to its members. Similarly, Wardaugh (1992) defines culture as to know how that a person must possess to get through the task daily living. This story can also be related to race which specifies on temperament (Sapir, 1949). Here Sutiasih an Indonesian woman working in Singapore as a midwife shows her dedication and loyalty not only to her parents but also to her employer. As Indonesian woman she is patient (temperament), and this can be seen from the expression of taking care ama (grandma) and child. She is also responsible for the life of her family by sending half of her money to her family.

Her relation with her employer is good. In this story Sutiasih has the right to have holiday and she expresses her joy about her holiday. Another good relation can be seen from her expression of my ama (grandma) in the sentence of the last paragraph. Grandma here is the mother of her employer, however because of her close-ness she calls my ama. The ama lives together with her employer. This is a typical Asian culture, that when someone has lived for a long time with a family, there will be a psychological bound to make them relatives that grow among them without considering their race, tribe and religion. 


\section{Conclusion}

As the study of lexical semantics, ethnosemantics has relation with meaning, words nuances, culture and race. Everyday Singlish shows all these. In order to learn everyday Singlish contextually, ethnosemantics is capable of discovering the richness of Singlish with several illustrative samples showing the culture, characteristics, and the everyday life of Singaporeans. Therefore,ethnosemantics provides another perspective of language use that sounds unique, local and unstandardized. This study is also needed to enrich the culture knowledge in order to be able to adjust quickly in a certain speech community.

\section{REFERENCES}

Blair, Robert W. 1982. Innovative Approach to Language Teaching. London: Newbury House Publishers.

Cooper, David E. 1979. Philosophy and the Nature of Language. London: Longman Group Limited.

Gass, Susan and Selinker, Larry. 1994. Second Language Acquisition: An Introductory Course. New Jersey: Lawrence Erlbaum Associates.

Hymes, Dell. H ,1974, The Ethnography of Speaking in language, Culture and Society. edited by Blount, Ben G. Cambridge: Winthrop Publishers, Inc.

Muhrofi Gunadi, Kun A. 2000, Model Bahasa Inggris Aksen Singapura Melalui Listening Bagi Mahasiswa Program Diploma III Pariwisata Universitas Merdeka Malang. Penelitian DP3M Dikti, Departemen Nasional, unpublished.

Romaine, Suzanne.1982. Sociolinguistic Variation in Speech Communities. London: Edward Arnold.

Sanchez, Mary and Blount, Ben G. 1994. Sociocultural Dimensions of Language Use. New York: Academic Press.

Sapir, Edward. 1949, Language: An Introduction to the Study of Speech. San Diego: A Harvest/HBJ Book, Harcourt Brace Jovanovich.

Sibayan, Bonifacio P.1984, Teaching for Communicative Competence in a Second Language in Communicative Language Teaching edited by Das Bikram K 1984. Singapore: Singapore University Press for SEAMEO Regional Language Center.

Syafiyah, 2004. Language Thought and Culture in The Nature of Language: Many-Sided Approaches to its Opaqueness edited by Fatubun, R and Basthomi, Y. Malang: Hybrid Press Malang. 